\title{
Spatial distribution of tuberculosis in indigenous and non-indigenous populations in the state of Pará, Brazil, 2005-2013
}

Distribuição espacial de tuberculose nas populações indígenas e não indígenas do estado do Pará, Brasil, 2005-2013

Distribución espacial de la tuberculosis en indígenas y no indígenas del estado de Pará, Brasil, 2005-2013

Bárbara Lopes Paiva ${ }^{1}$ Jéssica Quelé Azeredo ${ }^{1}$

Laura Maria Vidal Nogueira ${ }^{1}$ Bruno de Oliveira Santos ${ }^{1}$

Ivaneide Leal Ataide Rodrigues ${ }^{1}$ Marcandra Nogueira de Almeida Santos ${ }^{1}$

1. Universidade do Estado do Pará. Belém, PA, Brazil.
Corresponding author:

Bárbara Lopes Paiva.

E-mail: barbaralopespaiva@gmail.com

Submitted on 05/13/2017.

Accepted on 07/19/2017.

DOI: 10.1590/2177-9465-EAN-2017-0135

\section{Abstract}

Objective: To analyze the incidence of tuberculosis in indigenous and non-indigenous residents in the state of Pará from 2005-2013. Method: An ecological study was performed with data from SINAN, stratified for the 13 existing Regional Health Centers in Pará. The tuberculosis incidence rates were calculated for indigenous and non-indigenous populations in the 13 regions and maps were prepared to visualize the magnitude of the occurrence of tuberculosis. Results: Significant differences in the incidence of tuberculosis were found among non-indigenous and indigenous populations, reaching 7,812/100,000 inhabitants and 118/100,000 inhabitants respectively. Conclusion: Tuberculosis was distributed heterogeneously among the indigenous and non-indigenous populations. Moreover, it was possible to identify areas with high risk for this disease. It is important to note that knowledge about priority areas for tuberculosis control can help health service management to improve indicators that assess this disease and to develop different policies for indigenous peoples.

Keywords: Tuberculosis; Indigenous Population; Spatial Analysis.

\section{RESUMO}

Objetivo: Analisar a ocorrência de tuberculose nas populações indígenas e não indígenas residentes no estado do Pará entre 2005-2013. Método: Estudo ecológico realizado a partir de dados do SINAN, estratificados para os 13 Centros Regionais de Saúde existentes no Pará. Foram calculadas taxas de incidência de tuberculose para indígenas e não indígenas nas 13 regiões e confeccionados mapas para visualização da magnitude da ocorrência de tuberculose. Resultados: Encontraram-se diferenças marcantes na incidência de tuberculose entre população indígena e não indígena, alcançando 7.812/100 mil habitantes e 118/100 mil habitantes, respectivamente. Conclusão: Observou-se que a tuberculose se distribuiu heterogeneamente entre a população indígena e não indígena, sendo possível identificar regiões com alto risco de adoecimento. É importante ressaltar que o conhecimento de regiões prioritárias para o controle de tuberculose, pode auxiliar a gestão dos serviços de saúde para melhores indicadores que avaliam a doença, bem como desenvolver políticas diferenciadas para os povos indígenas.

Palavras-chave: Tuberculose; População Indígena; Análise Espacial.

\section{Resumen}

Objetivo: Analizar la incidencia de la tuberculosis en los residentes indígenas y no indígenas en el estado de Pará entre 2004-2013. Método: Estudio ecológico partir de datos del SINAN, estratificado para los 13 Centros Regionales de Salud existentes en Pará. Se calcularon las tasas de incidencia de tuberculosis en indígenas y no indígenas en las 13 regiones, y se confeccionaron los mapas para visualizar la magnitud de la incidencia de la tuberculosis. Resultados: Se encontró diferencias significativas en la incidencia de la tuberculosis entre la población no indígena y indígena, llegando a 7.812/100 mil habitantes y 118/100 mil habitantes. Conclusión: Se observó que la tuberculosis presenta una distribución heterogénea entre la población indígena y no indígena, y se pudo identificar las zonas con alto riesgo de la enfermedad. Es importante tener en cuenta que el conocimiento de las áreas prioritarias para el control de la tuberculosis puede ayudar a la gestión de los servicios de salud, para mejorar los índices que evalúan la enfermedad y desarrollar diferentes políticas para los pueblos indígenas.

Palabras clave: Tuberculosis; Población Indígena; Análisis Espacial. 


\section{INTRODUCTION}

Tuberculosis (TB) is a relevant endemic disease that affects indigenous populations. ${ }^{1}$ According to the Programa Nacional de Controle da Tuberculose (PNCT - Brazilian Program on Tuberculosis Control), this group is considered to be vulnerable to such disease. ${ }^{2}$ Scientific evidence ${ }^{3-5}$ indicates that the incidence of TB is high in these populations, reaching rates ret-7 $^{3-7}$ that are ten times higher than those found in the general Brazilian population.

A total of 9.6 million new cases of tuberculosis were estimated in 2014. Worldwide, 1.5 million individuals died of this disease. ${ }^{8}$ According to the 2015 Epidemiological Bulletin, ${ }^{9}$ the TB incidence rate for the general population was $44.4 / 100,000$ inhabitants in Northern Brazil and 39.2/100,000 inhabitants in the state of Pará, higher than the Brazilian mean of 33.5/100,000 inhabitants.

Although representing only $0.4 \%$ of the Brazilian population ${ }^{10}$ in 2014 , nearly $1.1 \%$ of all new cases of TB were reported for this segment of the population in Brazil. ${ }^{9}$

In the context of indigenous populations being infected with $T B$, it should be noted that there is insufficient knowledge about the epidemiological profile of these populations, due to vulnerabilities in the data record system for mortality and morbidity, among others. ${ }^{11}$ These vulnerabilities are associated with incomplete data and possible underreporting, as a result of the geographical characteristics of the spaces where they are produced.

Moreover, in Brazil, these databases originated from the health services provide important information that can be used to support the development of public policies, planning and service management. ${ }^{12}$ When analyzed with spatial analysis techniques, such as geoprocessing, they can contribute to increase knowledge about the behavior of a disease in a certain geographical area, aiming to outline appropriate strategies for disease reduction and transmission that prioritize more vulnerable populations, such as indigenous populations. ${ }^{13}$

In the 2010 census, ${ }^{10}$ the Brazilian indigenous population totaled nearly 896,917 individuals, of which 342,800 lived in Northern Brazil. In the state of Pará, there were 39,081 indigenous people divided into 30 ethnic groups (Munduruku, Kaiapó and Parakanâ, among others), spread across 298 villages. Indigenous lands covered $24.52 \%$ of the total area of this state. ${ }^{14}$

Health services caring for indigenous populations are organized according to the Indigenous Health Care Subsystem, which is part of the Sistema Único de Saúde (SUS - Unified Health System). Decree number 3156, issued on August $27^{\text {th }}$ 1999, regulated the Política Nacional de Atenção à Saúde dos Povos Indígenas (PNASPI - National Policy on Indigenous Health Care) and recommended the implementation of a distinct complementary model of organization of services for indigenous health protection, promotion and recovery. ${ }^{15}$

PNASPI operationalization occurs through 34 Distritos Sanitários Especiais Indígenas (DSEI - Special Indigenous Health Districts). These DSEI are operational units that seek to respect the culture, political relations and ancestral indigenous population distribution. Thus, there are specific geographical and technical-operational criteria not coinciding with the territorial boundaries of states and/or cities in which the indigenous lands are located. For this reason, the DSEl are under the responsibility of the federal government and they are associated with the Secretaria Especial de Atenção à Saúde Indígena (SESAI Special Department of Indigenous Health Care).${ }^{15}$ In the state of Pará, this operationalization occurs through the following four DSEl: Altamira; Guamá Tocantins, Kaiapó Pará and Rio Tapajós. $^{16}$

The present study aimed to spatially identify and describe the occurrence of tuberculosis in indigenous and non-indigenous populations living in the state of Pará between 2005 and 2013, aiming to contribute to greater disease control, as it indicates regional health centers and the respective cities with higher incidence of tuberculosis in indigenous and non-indigenous populations.

\section{METHODS}

An ecological study was performed from data on TB reported to the Sistema de Informação de Agravos e Notificação (SINAN - Notifiable Diseases Information System). The study setting was the state of Pará, Northern Brazil, which is divided into 144 cities and has an estimated population of 7,969,654 inhabitants. ${ }^{17}$ Researchers chose to gather data on cities according to the group of 13 Centros Regionais de Saúde (CRS - Regional Health Centers), which organize this state for health management purposes.

In accordance with Presidential Decree number 7508/2011, a health region is a continuous geographical space formed by cities that share cultural, economic and social identities, and communication and transport networks, aiming to integrate, organize, plan and execute health services and actions. ${ }^{18}$ To evaluate tuberculosis cases according to such geographic units provides resources for better planning and strengthening of SUS coordinators. As a result, this reaffirms the assumptions made by Law $8080 / 1990^{19}$ and Decree $4279 / 2010^{20}$ that emphasize the importance of regionalization as a structure foundation for the Management Pact, which foresees the decentralization of health services and actions and the organization of the Health Care Network. This takes into consideration that managers coordinating the Regional Health Centers must improve their planning according to territorial demands, epidemiological profile and social indicators. As a result, this will enable better resolvability of problems affecting the population.

Calculations took into account the total number of cases reported to the SINAN between January $1^{\text {st }} 2004$ and December $21^{\text {st }} 2013$, regardless of ethnicity. Data were obtained from the State Coordination for Tuberculosis Control of the Secretaria de Estado de Saúde Pública do Estado do Pará (SESPA - Pará State Department of Public Health) and made available as a database including the following variables: number of new cases of TB by ethnicity, according to city of occurrence. 
For data treatment, depuration was initially performed using the EpilNfo 7 software program, aiming to select the most relevant variables to achieve the study objectives and avoid possible biases, such as incompleteness, redundancies and inconsistencies.

Next, the Banco de Dados Geográfico (BDGEO - Geographic Database) on reported cases in the study area and period was constructed. After data consistency was analyzed, a total of 34,495 cases were exported to a 2010 Microsoft $^{\circledR}$ Office Excel ${ }^{\circledR}$ spreadsheet. This enabled the calculation of TB incidence rates in each city, using demographic data originated from the 2010 IBGE (Brazilian Institute of Geography and Statistics) census through the following expression: $\mathrm{N}$ of new case of a disease occurring in a population in a certain period $x 1,000 / \mathrm{N}$ of individuals at risk of being infected by this disease during the same period. ${ }^{21}$

TB incidence rates were subsequently associated with geographical coordinates (latitudes and longitudes) of each city obtained from the IBGE website, aiming to transform data into spatial information. Next, this information was processed using the ArcGis 10.2 software program to generate maps, according to the study objective.

Aiming to better visualize the georeferenced data on maps, the years analyzed were grouped into three-year periods: 2005-2007, 2008-2010, 2011-2013. A historical series of TB incidence coefficients was constructed for the indigenous and non-indigenous populations by city, grouped according to CRS composition.

In accordance with Resolution 466/2012 - CNS/MS, which regulates research on human beings, the present study was submitted to the Research Ethics Committee of the UEPA Nursing Course and approved on June $24^{\text {th }} 2014$, under official opinion number 698247. Before data were obtained from the Pará State Department of Public Health, the Termo de Autorização de Acesso ao Banco de Dados (TAABD - Database Access Authorization Term) had to be signed and all ethical principals were followed.

\section{RESULTS}

Among the indigenous and non-indigenous populations living in the state of Pará between 2005 and 2013, there were 31,071 new cases of TB, reaching an annual mean of 3,452 reports. When these cases were stratified, $98.6 \%(n=30,666)$ corresponded to non-indigenous individuals. There were 405 new cases $(1.3 \%$ of the total number) in the indigenous population.

The coefficient of mean incidence of TB in the state of Pará between 2005 and 2013 was 45.8/100,000 inhabitants for the general population; $46.0 / 100,000$ inhabitants for the nonindigenous population; and 115.16/100,000 inhabitants for the indigenous population. According to the city of residence, the spatial analysis of incidence rates showed significant differences in mean coefficients of incidence of TB between indigenous and non-indigenous populations in several health regions.
Regarding the non-indigenous population, in the three-year period of $2005-2007$, the $1^{\text {st }}, 3^{\text {rd }}, 4^{\text {th }}, 6^{\text {th }}, 9^{\text {th }}$ and $10^{\text {th }}$ CRS showed high incidence rates equal to or higher than 50 new cases per 100,000 inhabitants. The cities of Belém ( $1^{\text {st }} \mathrm{CRS}$ ), Ananindeua ( $\left.1^{\text {st }} \mathrm{CRS}\right)$, Marituba ( $\left.1^{\text {st }} \mathrm{CRS}\right)$, Maracanã ( $\left.3^{\text {rd }} \mathrm{CRS}\right)$, Cachoeira do Piriá ( $\left.4^{\text {th }} \mathrm{CRS}\right)$, Capanema (4 $\left.{ }^{\text {th }} \mathrm{CRS}\right)$, São João de Pirabas ( $\left.4^{\text {th }} \mathrm{CRS}\right)$, Novo Progresso (9 $\left.9^{\text {th }} \mathrm{CRS}\right)$, Oriximiná (9 $\left.9^{\text {th }} \mathrm{CRS}\right)$, Barcarena ( $\left.6^{\text {th }} \mathrm{CRS}\right)$ stood out, as they had incidence rates between 60.3 and 83.6 new cases per 100,000 inhabitants, according to Figure 1.

In this same three-year period, there was a great difference in coefficients of incidence between the indigenous and non-indigenous populations. Among the indigenous people, values of coefficient of mean incidence higher than 100 new cases per 100,000 inhabitants were identified in the $1^{\text {st }} \mathrm{CRS}$, $3^{\text {rd }} \mathrm{CRS}, 5^{\text {th }} \mathrm{CRS}, 9^{\text {th }} \mathrm{CRS}, 10^{\text {th }} \mathrm{CRS}, 11^{\text {th }} \mathrm{CRS}$ and $12^{\text {th }} \mathrm{CRS}$. In the $12^{\text {th }} \mathrm{CRS}$, there were significantly higher values in the cities of Santana do Araguaia, with 7,462.6 new cases per 100,000 inhabitants; Tucumã, with 7,812 new cases per 100,000 inhabitants; and Banach, with 1,602.5 new cases per 100,000 inhabitants (Figure 1).

In the three-year period of 2008-2010, the map of data on the non-indigenous population showed a reduction in the rates in certain regional health centers, except for the $1^{\text {st }} \mathrm{CRS}, 3^{\text {rd }} \mathrm{CRS}, 4^{\text {th }}$ CRS and $9^{\text {th }} \mathrm{CRS}$, which still had high rates in this period, ranging between 57.2 and 78.2 new cases per 100,000 inhabitants. In the same period, the $2^{\text {nd }} \mathrm{CRS}$ showed an incidence rate between 53.6 and 62 new cases per 100,000 inhabitants, thus higher than the previous three-year period (Figure 1).

Additionally, in the three-year period of 2008-2010, although there was a reduction in the coefficients of incidence among the indigenous population in the $1^{\text {st }} \mathrm{CRS}, 3^{\text {rd }} \mathrm{CRS}, 5^{\text {th }} \mathrm{CRS}, 9^{\text {th }}$ CRS, $10^{\text {th }} \mathrm{CRS}, 11^{\text {th }} \mathrm{CRS}$ and $12^{\text {th }} \mathrm{CRS}$, these values remained higher than 100 new cases per 100,000 inhabitants, except for Jacareacanga ( $9^{\text {th }} \mathrm{CRS}$ ) and Santana do Araguaia (12 $\left.{ }^{\text {th }} \mathrm{CRS}\right)$, whose rates were lower than 50/100,000 inhabitants (Figure 1).

In the last three-year period analyzed, 2011-2013, the rates for the non-indigenous population in the $1^{\text {st }} \mathrm{CRS}, 2^{\text {nd }} \mathrm{CRS}, 4^{\text {th }} \mathrm{CRS}$ and $9^{\text {th }} \mathrm{CRS}$ remained high, especially in Belém, with 101.7 new cases per 100,000 inhabitants, and Santa Izabel do Pará, with 118 new cases per 100,000 inhabitants (Figure 1).

Likewise, among the indigenous population, there were coefficients of incidence higher than 100 new cases per 100,000 inhabitants in almost all Regional Health Centers, varying from 132 to 1,149 new cases per 100,000 inhabitants, except for the $5^{\text {th }}$ CRS, $7^{\text {th }} \mathrm{CRS}$ and $10^{\text {th }} \mathrm{CRS}$, which almost always showed lower values, ranging from 0 to 90 new cases per 100,000 inhabitants (Figure 1).

It should be emphasized that the cities of Bragança $\left(4^{\text {th }} \mathrm{CRS}\right)$, Cametá (1 $\left.3^{\text {th }} \mathrm{CRS}\right)$, Curuçá ( $\left.3^{\text {rd }} \mathrm{CRS}\right)$, Novo Progresso ( $9^{\text {th }} \mathrm{CRS}$ ) and Ulianópolis $\left(5^{\text {th }} \mathrm{CRS}\right)$ showed incidence rates higher than 1,000 new cases per 100,000 inhabitants in the three-year period of 2011-2013, as shown in Figure 1. 
Figure 1. Distribution of TB cases in the indigenous and non-indigenous populations reported between 2005-2013, state of Pará, Northern Brazil, 2017. Source: Sistema Nacional de Agravos e Notificação (SINAN - Notifiable Diseases National System), 2005-2013.

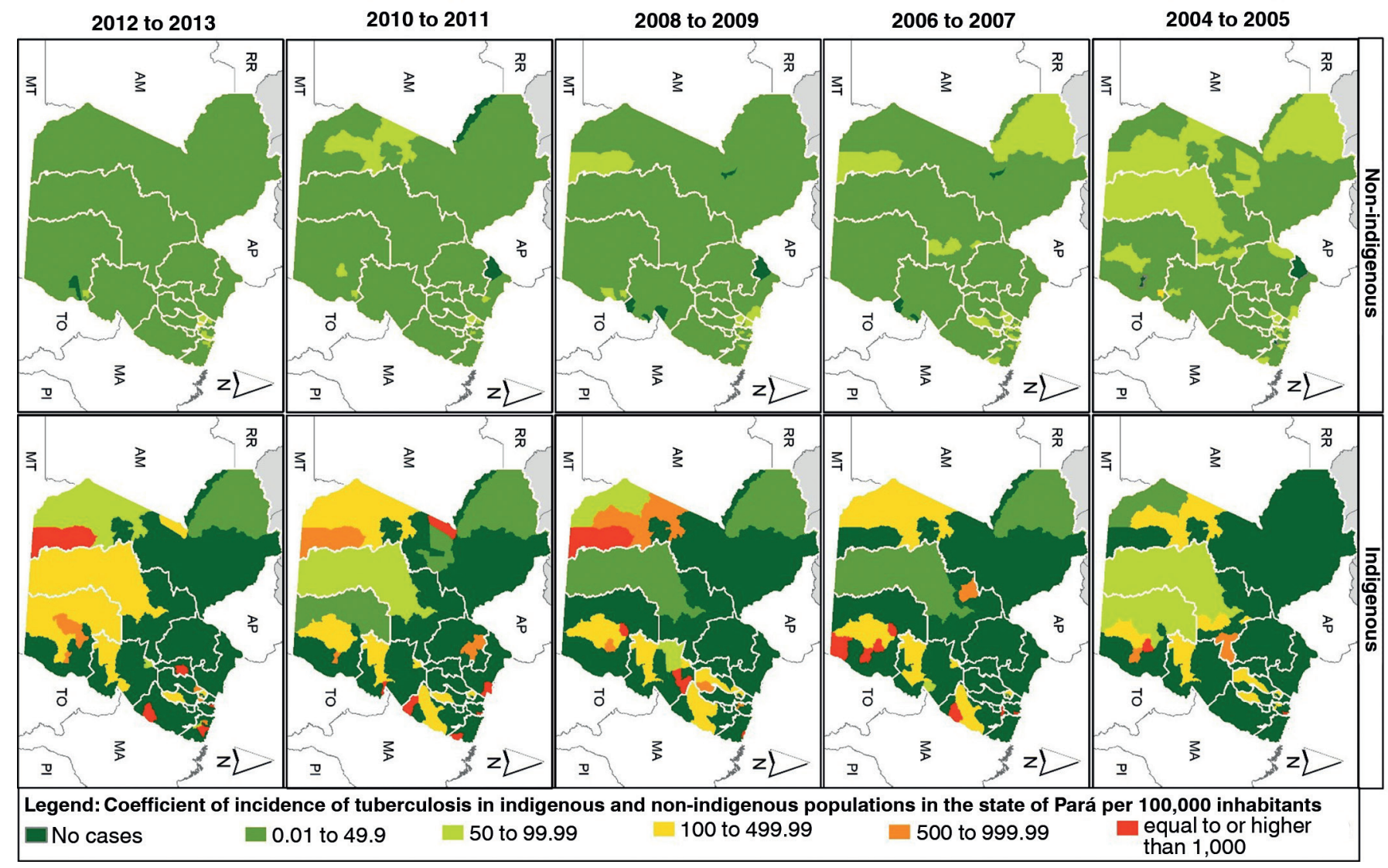

\section{DISCUSSION}

Through spatial analysis of health, TB was found to have spread among indigenous and non-indigenous populations heterogeneously. Thus, it is possible to visualize the CRS and, consequently, the cities covered by them where there are high values and significant differences between such populations, reaching 7,812 new cases per 100,000 inhabitants among indigenous populations and 118 new cases per 100,000 inhabitants among non-indigenous populations, values considered to be higher than the mean for Pará state.

The representativeness of TB reports among indigenous populations was $1.3 \%$ of the total recorded in the SINAN on average. However, this population group represents nearly $0.47 \%$ of the total population in the period analyzed. These data show a higher incidence in such population, according to studies which concluded that indigenous groups are the most vulnerable to TB infection. ${ }^{22-25}$

Regarding the georeferenced analysis of TB cases in nonindigenous populations, few cities showed a decrease in the mean coefficient of incidence during the transition from the 2005-2007 to the 2008-2010 three-year period. Nonetheless, there was a steady reduction in the incidence of cases in the group of cities included in the $6^{\text {th }}$ and $10^{\text {th }}$ CRS. This evidence could be a reflection of the implementation of control actions in both regions. However, the data available do not enable any further analyses in this sense.

Moreover, among non-indigenous populations, the threeyear period of 2011-2013 showed a coefficient of incidence of 118 new cases per 100,000 inhabitants for the $1^{\text {st }}$ CRS in the city of Santa Izabel, suggesting a possible worsening of the measures for disease control in this CRS. Santa Izabel do Pará is part of the metropolitan area of the city of Belém, where there is insufficient infrastructure and basic sanitation to meet the population needs. The high incidence rate of TB in this city is probably associated with socioeconomic conditions. Some studies $^{26-29}$ point to TB incidence being higher in areas with poorer socioeconomic and housing conditions and low level of education.

More high incidence rates were found in other studies of Brazilian cities. However, they are not as high as the value found for the non-indigenous population in these cities, in the state of Pará. A study ${ }^{30}$ on the spatial distribution of TB performed in the city of Teresina, Piauí state, between 2005 and 2007, found a mean incidence rate of 39.3 new cases per 100,000 inhabitants.

The georeferenced analysis of data on the indigenous populations was found to be significantly different from that performed with data from the non-indigenous populations, as coefficients of incidence were much higher. This epidemiological condition can be justified by the low level of socioeconomic 
development and poor health service conditions found in indigenous areas, which has been confirmed in studies on TB cases and socioeconomic conditions. ${ }^{31,32}$

A study ${ }^{33}$ performed with an indigenous population in the city of Dourados, Mato Grosso do Sul state, revealed that appalling conditions of health and malnourishment were associated with an increase in TB. Moreover, it showed that malnourishment combined with very poor housing conditions with a high density of residents and a single room without ventilation facilitated TB infection.

During the three three-year periods, among indigenous populations, the values of coefficients of incidence remained high and did not vary significantly between 132 and 1,149 new cases per 100,000 inhabitants. However, the three-year period of 2008-2010 stood out with high rates in the cities of Santana do Araguaia, Tucumã and Banach, which can be partly explained by the possible vulnerabilities of TB control actions in this period in neighboring cities or greater demand for indigenous health services in such cities.

The city of Banach has an indigenous health clinic. Additionally, the DSEI Kaiapó of Pará state is comprised of this city and four other cities (Cumaru do Norte, Pau D'arco, Ourilândia do Norte and São Felix do Xingú) and located in its Southern region, on the border with Mato Grosso and Tocantins states. In this DSEl, the indigenous population includes 4,879 individuals from the Kayapó ethnic group, distributed into 1,578 families living in 45 villages. ${ }^{34}$

In this sense, high rates of TB infection were also found in studies on spatial distribution performed in indigenous lands and cities in the state of Rondônia, ${ }^{35}$ with coefficients of incidence of $415.03 / 100,000$ inhabitants for the indigenous population between 1997 and 2006, and, in cities in the Amazon region on the border between Brazil, Colombia, Peru and Venezuela, with a mean coefficient of incidence ranging between 202.3 and $65.6 / 100,000$ inhabitants for the indigenous population from 2001 to $2010 .{ }^{36}$

Additionally, the three-year period of 2011-2013 should be emphasized, when the $3^{\text {rd }}$ CRS (Curuçá), $4^{\text {th }}$ CRS (Bragança), $5^{\text {th }}$ CRS (Ulianópolis), $9^{\text {th }}$ CRS (Novo Progresso) and $13^{\text {th }}$ CRS (Cametá) showed an incidence higher than 451 new cases/100,000 inhabitants. Among all these cities, Novo Progresso is the only one that has a specific service for indigenous populations, thus suggesting better investigation of TB cases or even the migration of indigenous populations from other cities, seeking better health care. The city of Novo Progresso is in the area covered by the DSEI Rio Tapajós, located in Southwest Pará state with a population of 8,121 indigenous individuals, distributed across 86 villages. In this DSEI, the Munduruku ethnic group predominates. ${ }^{37}$

A study ${ }^{38}$ concluded that the migration of human groups has contributed to the dissemination of infectious diseases such as TB. Another study ${ }^{39}$ on the dynamics of migration in the Mediterranean Sea and the differences in infectious diseases from the places of origin raised the question of whether public health actions are sufficient to prevent the transmission of infectious diseases.

It is possible to identify that the geographical dynamics of occurrence of TB behaves differently in terms of ethnic groups, which were indigenous and non-indigenous populations in the case of the present study. Consequently, as this finding is appreciated, the city or even regional health management can implement TB control actions, aiming to structure an effective service network that includes culturally diverse care, aiming to meet the requirements of indigenous populations.

The organizational model for health management in the state of Pará should be emphasized, regulated by regionalization and with cities being grouped according to the criteria established by the Comissão Intergestores Bipartite (CIB - Bipartite InterManager Committee).$^{40}$ Thus, studies with this format can provide resources for the planning and implementation of health care actions. Although all the DSEls are responsible for primary health care for indigenous populations, they are located in geographical spaces comprising regional health centers. Therefore, they should be valued, as indigenous populations often go to urban areas in cities for different reasons, promoting frequent contact.

Finally, the analysis of the present study revealed inequalities in TB indicators between indigenous and non-indigenous populations, avoiding the need for specific actions in the cities, according to the human group most vulnerable to this disease. To achieve this, investment is essential to improve health service structuring, so that TB cases present in the community can be diagnosed and treated, thus meeting the goals established for disease control. Furthermore, the results of this study reflect the challenge of including appropriate strategies for TB control in minority ethnic groups of the Brazilian population into the health services.

The present study has limitations and data must be interpreted with caution. This is because the analysis of data on TB incidence was based on SINAN records, which provides information subject to data incompleteness, underreporting and incorrect recording, like other health information systems in Brazil.

\section{CONCLUSION}

Based on the findings of the present study, it could be concluded that the indigenous populations in the state of Pará need more attention regarding adequate TB control. The use of spatial analysis allowed for knowledge about the distribution of TB among indigenous and non-indigenous populations and the clear visualization of areas with higher concentration of cases according to the Regional Health Centers.

Mapping of the coefficients of incidence of TB in the entire state enabled the identification of priority areas that require a special intervention. Additionally, if appreciated in the epidemiological surveillance routine, this can be useful to outline appropriate strategies to reduce TB transmission, apart from contributing to measures recommended by the PNCT being prioritized in these locations. Thus, a more favorable context for TB control in this state can be more easily achieved. 


\section{ACKNOWLEDGEMENTS}

Authors would like to thank the Laboratório de Epidemiologia e Geoprocessamento (EPIGEO - Laboratory of Epidemiology and Geoprocessing); the Centro de Ciências Biológicas da Saúde (CCBS - Biological Sciences Health Center); the Universidade do Estado do Pará (UEPA - Pará State University), Belém, Pará state, Northern Brazil; and the Programa Institucional de Bolsas de Iniciação Científica (PIBIC - Institutional Program on Undergraduate Project Scholarships).

\section{REFERENCES}

1. Resende LP, Rodrigues L, Menegócio AM. Realidade da Tuberculose nos Indígenas Brasileiros com Diversidade de Etnias em Menores de 15 Anos de Idade. Ensaios Cienc Cienc Biol Agrar Saúde [Internet]. 2014; [cited 2016 Dec 17]; 18(2):105-11. Available from: http://www. redalyc.org/articulo.oa?id=26042164006

2. Ministério da Saúde (BR). Secretaria de Vigilância em Saúde. Manual de recomendações para o controle da tuberculose no Brasil. Brasília: Ministério da Saúde; 2011.

3. Escobar AL, Coimbra Junior CEA, Camacho LA, Portela MC. Tuberculosis among indigenous populations in Rondonia, Amazonia, Brazil. Cad Saúde Pública [Internet]. 2001 Apr; [cited 2016 Oct 5]; 17(2):285-98. Available from: http://dx.doi.org/10.1590/S0102$311 \times 2001000200004$

4. Gava C, Malacarne J, Rios DPG, Sant'Anna CC, Camacho LAB, Basta PC. Tuberculose em crianças indígenas da Amazônia brasileira. Rev Saúde Pública [Internet]. 2013 Feb; [cited 2016 Oct 5]; 47(1):77-85. Available from: http://dx.doi.org/10.1590/S0034-89102013000100011

5. Nogueira LMV, Teixeira E, Basta PC, Motta MCS. Therapeutic itineraries and explanations for tuberculosis: an indigenous perspective. Rev Saúde Pública [Internet]. 2015 Jan 22; [cited 2016 Oct 5]; 49:96. Available from: http://dx.doi.org/10.1590/S0034-8910.2015049005904

6. Lachi T, Nakayama M. Radiological findings of pulmonary tuberculosis in indigenous patients in Dourados, MS, Brazil. Radiol Bras [Internet]. 2015 Sep-Oct; [cited 2016 Oct 5]; 48(5):275-81. Available from: http:// dx.doi.org/10.1590/0100-3984.2014.0070

7. Basta PC, Marques M, Oliveira RL, Cunha EAT, Resendes APC, SouzaSantos R. Desigualdades sociais e tuberculose: análise segundo raça/ cor, Mato Grosso do Sul. Rev Saúde Pública [Internet]. 2013 Oct; [cited 2016 Oct 5]; 47(5):854-64. Available from: http://dx.doi.org/10.1590/ S0034-8910.2013047004628

8. World Health Organization. Global Tuberculosis Report 2015. [Internet]. Geneva:World Health Organization;2015 [cited 2016 Jul5].Available from: http://apps.who.int/iris/bitstream/10665/191102/1/9789241565059_ eng.pdf

9. Ministério da Saúde (BR). Boletim epidemiológico. Brasília: Ministério da Saúde; 2015.

10. Instituto Brasileiro de Geografia e Estatística (BR). Os indígenas no Censo Demográfico 2010/Primeiras considerações com base no quesito cor ou raça; 2012 [cited 2016 Oct 5]. Available from: http:// www.ibge.gov.br/indigenas/indigena_censo2010.pdf

11. Malacarne J. Tuberculose na população indígena de Rondônia: caracterização do acesso aos serviços de saúde e diagnóstico situacional entre os Wari da aldeia Igarapé Ribeirão [dissertação]. Rio de Janeiro (RJ): Escola Nacional de Saúde Pública Sergio Arouca; 2013.

12. Opromolla PA, Dalben I, Cardim M. Análise da distribuição espacial da hanseníase no Estado de São Paulo, 1991-2002. Rev Bras Epidemiol [Internet]. 2005 Dec; [cited 2016 Oct 5]; 8(4):356-64. Available from: http://dx.doi.org/10.1590/S1415-790X2005000400004
13. Garnelo L, Brandão LC, Levino A. Dimensões e potencialidades dos sistemas de informação geográfica na saúde indígena. Rev Saúde Pública [Internet]. 2005 Mar; [cited 2016 Oct 5]; 39(4):634-40. Available from: http://dx.doi.org/10.1590/S0034-89102005000400018

14. Ministério da Justiça (BR). Fundação Nacional do Índio. Povos e terras indígenas [cited 2016 Oct 5]. Available from: http://www.funai.gov.br/ index.php/indios-no-brasil/quem-sao

15. Ministério da Saúde (BR). Política nacional de atenção à saúde dos povos indígenas. $2^{\underline{a}}$ ed. Brasília: Ministério da Saúde; 2002.

16. Secretaria de Estado e Saúde Pública (PA). Plano estadual de saúde do Pará/PESPA 2012 - 2015; 2012 [cited 2016 Oct 5]. Available from: https://www2.mppa.mp.br/sistemas/gcsubsites/upload/37/PES-20122015.pdf

17. Instituto Brasileiro de Geografia e Estatística (BR). Estado do Pará [cited 2016 Oct 5]. Available from: http://www.ibge.gov.br/estadosat/ perfil.php?sigla $=p a$

18. Decreto $n^{\circ} \mathbf{7 . 5 0 8}$, de 28 junho de 2011 (BR). Regulamenta a Lei $n^{\circ}$ 8.080, de 19 de setembro de 1990, para dispor sobre a organização do Sistema Único de Saúde - SUS, o planejamento da saúde, a assistência à saúde e a articulação interfederativa, e dá outras providências. Diário Oficial da União. Brasília (DF). 29 jun 2011 [cited 2016 Oct 5]. Available from: http://www.planalto.gov.br/ccivil_03/_ato2011-2014/2011/ decreto/d7508.htm

19. Lei $\mathrm{n}^{\circ} 8.080$, de 19 de setembro de 1990. Dispõe sobre as condições para a promoção, proteção e recuperação da saúde a organização e o funcionamento dos serviços correspondentes e dá outras providências. Diário Oficial da União [periódico na internet]. Brasília (DF). 19 jun 1990 [cited 2017 Jun 9]. Available from: http://www.planalto.gov.br/ccivil_03/ leis/L8080.htm

20. Portaria $\mathrm{n} \times 4.279$, de 30 de Dezembro de 2010. Estabelece diretrizes para a organização da Rede de Atenção à Saúde no âmbito do Sistema Único de Saúde (SUS). Diário Oficial da União [periódico na internet]. Brasília (DF). 30 dez 2010 [cited 2017 Jun 9]. Available from: http://bvsms. saude.gov.br/bvs/saudelegis/gm/2010/prt4279_30_12_2010.html

21. Medronho RA, Bloch KV, Luiz RR, Werneck GL, orgs. Epidemiologia. $2^{\mathrm{a}}$ ed. São Paulo: Atheneu; 2009.

22. Secretaria de Estado da Saúde (GO). A Tuberculose entre as Populações Vulneráveis no Estado de Goiás no ano de 2015 [cited 2016 Oct 5]. Available from: http://www.sgc.goias.gov.br/upload/ arquivos/2016-04/boletim-epidemiologico-tb-vulnerabilidades-20161. pdf

23. Basta PC, Coimbra Junior CEA, Escobar AL, Santos RV. Aspectos epidemiológicos da tuberculose na população indígena suruí, Amazônia, Brasil. Rev Soc Bras Med Trop [Internet]. 2004 Aug; [cited 2016 Oct 5]; 37(4):338-42. Available from: http://dx.doi.org/10.1590/ S0037-86822004000400010

24. Basta PC, Coimbra Junior CEA, Welch JR, Alves LCC, Santos RV, Camacho LAB. Tuberculosis among the Xavante Indians of the Brazilian Amazon: an epidemiological and ethnographic assessment. Ann Hum Biol [Internet]. 2010 Oct; [Cited 2016 Oct 5]; 37(5):643-57. Available from: http://dx.doi.org/10.3109/03014460903524451

25. Ferraz AF, Valente JG. Epidemiological aspects of pulmonary tuberculosis in Mato Grosso do Sul, Brazil. Rev Bras Epidemio [Internet]. 2014 Feb; [cited 2016 Oct 5]; 17(1):255-66. Available from: http://www.scielosp.org/pdf/rbepid/v17n1/pt_1415-790Xrbepid-17-01-00255.pdf

26. Zhou C, Long Q, Chen J, Xiang L, Li Q, Tang S, et al. Factors that determine catastrophic expenditure for tuberculosis care: a patient survey in China. Infect Dis Poverty [Internet]. 2016 Jan 25; [cited 2016 Oct 5]; 5(1):6. Available from: http://idpjournal.biomedcentral.com/ articles/10.1186/s40249-016-0100-6

27. Marais BJ. The global tuberculosis situation and the inexorable rise of drug-resistant disease. Adv Drug Deliv Rev [Internet]. $2016 \mathrm{Jul}$; [Cited 2017 Jan 5]; 102:3-9. Available from: https://doi.org/10.1016/j. addr.2016.01.021 
28. Santos Neto M, Yamamura M, Garcia MCC, Popolin MP, Rodrigues LBB, Chiaravalloti Neto F, et al. Pulmonary tuberculosis in São Luis, State of Maranhão, Brazil: space and space-time risk clusters for death (20082012). Rev Soc Bras Med Trop [Internet]. 2015 Feb; [cited 2016 Oct 5]; 48(1):69-76. Available from: http://dx.doi.org/10.1590/0037-8682-02902014

29. San Pedro A, Oliveira RM. Tuberculose e indicadores socioeconômicos: revisão sistemática da literatura. Rev Panam Salud Publica [Internet]. 2013 Feb; [cited 2016 Oct 5]; 33(4):294-301. Available from: http://dx.doi. org/10.1590/S1020-49892013000400009

30. Montechi LN, Coêlho DMM, Oliveira CAR, Campelo V. Distribuição espacial da tuberculose em Teresina, Piauí, de 2005 a 2007. Epidemiol Serv Saúde [Internet]. 2013 Sep; [cited 2016 Oct 5]; 22(3):475-82. Available from: http://dx.doi.org/10.5123/S1679-49742013000300012

31. Comas I, Hailu E, Kiros T, Bekele S, Mekonnen W, Gumi B, et al. Population Genomics of Mycobacterium tuberculosis in Ethiopia Contradicts the Virgin Soil Hypothesis for Human Tuberculosis in Sub-Saharan Africa. Curr Biol [Internet]. 2015 Dec; [cited 2016 Oct 5];25(24):3260-6. Available from: $h$ ttp://dx.doi.org/10.1016/j.cub.2015.10.061

32. Sidon LU. Tuberculose nas populações indígenas de Rondônia (19972006) Amazônia ocidental - Brasil: Uma Análise com Base no SINAN [dissertação]. Rio de Janeiro (RJ): Escola Nacional de Saúde Pública Sergio Arouca; 2009.

33. Marques AMC, Cunha RV. A medicação assistida e os índices de cura de tuberculose e de abandono de tratamento na população indígena Guarani-Kaiwá no Município de Dourados, Mato Grosso do Sul, Brasil. Cad Saúde Pública [Internet].2003 Oct; [cited 2016 Oct 5]; 19(5):1405-11. Available from: http://dx.doi.org/10.1590/S0102-311X2003000500019

34. Ferreira JP. Mapa Provisório DSEI Kaiapó do Pará dos Fatores Intervenientes na Mortalidade Materna, Fetal e Infantil no DSEl e dos Itinerários de Produção de Saúde nas Áreas Indígenas; Brasília: Rede Humaniza SUS; 2013.
35. Melo TEMP, Resendes APC, Souza-Santos R, Basta PC. Distribuição espacial e temporal da tuberculose em indígenas e não indígenas em Rondônia, Amazônia ocidental, Brasil. Cad Saúde Pública [Internet] 2012 Feb; [cited 2016 Dec 17]; 28(2):267-80. Available from: http:// dx.doi.org/10.1590/S0102-311X2012000200006

36. Belo EN, Orellana JDY, Levino A, Basta PC. Tuberculose nos municípios amazonenses da fronteira Brasil-Colômbia-Peru-Venezuela: situação epidemiológica e fatores associados ao abandono. Rev Panam Salud Publica [Internet]. 2013 Nov; [cited 2016 Oct 5]; 34(5):321-9. Available from: http://www.scielosp.org/scielo.php?script=sci_arttext\&pid $=$ S1020-49892013001100004

37. Ministério da Saúde (BR). Fundação Nacional de Saúde (FUNASA) Distrito sanitário especial indígena do Rio Tapajós - sede: Itaituba - PA; 2001 [cited 2015 Aug 11]. Available from: www.bvsde.paho.org/bvsapi/p/ fulltext/distritos/riotapajos.pdf

38. Azarkar Z, Sharifzadeh G, Ebrahimzadeh A, Olumi S. Time to Sputum Smear Conversion in Smear-Positive Pulmonary Tuberculosis Patients and Factors for Delayed Conversion. Iran J Med Sci [Internet]. 2016 Jan; [Cited 2016 Oct 5]; 41(1):44-7. Available from: http://ijms.sums. ac.ir/index.php/IJMS/article/view/634/862

39. Napoli C, Dente MG, Kärki T, Riccardo F, Rossi P, Declich S; Network for the Control of Cross-Border Health Threats in the Mediterranean Basin and Black Sea. Screening for Infectious Diseases among Newly Arrived Migrants: Experiences and Practices in Non-EU Countries of the Mediterranean Basin and Black Sea. Int J Environ Rev Public Health [Internet]. 2015 Dec; [cited 2016 Oct 5]; 12(12):15550-8. Available from: http://www.mdpi.com/1660-4601/12/12/15002

40. Comissão Intergestores Bipartite do Sistema Único de Saúde do ParáCIB-SUSPA. Regionalização do estado do Pará;2013 Jun [cited 2015 Aug 11]. Available from: $\mathrm{http}: / /$ portalarquivos.saude.gov.br/images/pdf/2015/ junho/03/4.e\%20-\%20Oficio\%20e\%20Resolu\%C3\%A7\%C3\%A3०\%20 -\%20Regionaliza\%C3\%A7\%C3\%A30\%20PA.pdf 